\title{
Toxicity assessment of the methanol extract of Jatropha tanjorensis (Euphorbiaceae) leaves
}

\author{
C. Christian Chibuogwu* (D), U. Obioma Njoku, F. C. Okwesili Nwodo, E. O. Vincent Ozougwu and N. Victor Nweze
}

\begin{abstract}
Background: The leaves of Jatropha tanjorensis have been found to have important application both in traditional medicine and as an edible vegetable in Nigerian soups. It is popularly employed in Nigeria for the treatment of anemia, diabetes, and malaria. The dearth of information on its toxicity prompted this study. Mice were administered single oral doses of 10, 100, 1000, 1600, 2900, and $5000 \mathrm{mg} / \mathrm{kg}$ b.wt ( $\mathrm{n}=3 / \mathrm{group}$ ) of the extract and were observed for $24 \mathrm{~h}$ for any sign of toxicity and mortality in the acute toxicity study. For the sub-acute toxicity study, doses of 100, 200, and $400 \mathrm{mg} / \mathrm{kg}$ b.wt of the extract were administered to experimental rats ( $\mathrm{n}=6 / \mathrm{group}$ ) for 28 days after which the assessment of hematological and biochemical parameters, as well as liver and kidney histology was conducted post-treatment. Body weight of the animals was also taken weekly.

Results: The result showed that percentage weight gain decreased as the dose of extract increased. The haematological and biochemical parameters showed that the extract had no toxic effect on experimental animals, though there was a non-significant dose-dependent decrease in WBC. The extract also showed potential to cause hepatotoxicity at the highest dose.
\end{abstract}

Conclusion: Though the median lethal dose of the plant extract suggests relative safety of the plant material, consuming large amounts over a prolonged time may need to be discouraged to avoid potential damage to vital organs such as the liver.

Keywords: Jatropha tanjorensis, Sub-acute toxicity, Hepatotoxicity, Methanol extract

\section{Background}

For a long time, man has depended on plants for food and medicine and even with the development of several synthetic drugs and supplements, plants are still considered relevant in the maintenance of health and wellbeing of individuals. The uneven distribution of wealth in resource-poor regions of the world has also made plant-based therapeutic options the choice of many people due to the cheap availability of many therapeutically beneficial plants. The frequency of usage of traditional medicine in developing countries is about 40$90 \%$ according to the WHO [1]. Also, the rising

* Correspondence: christian.chibuogwu@unn.edu.ng

Department of Biochemistry, Faculty of Biological Sciences, University of Nigeria, Nsukka, Enugu State, Nigeria incidence of chronic metabolic diseases all over the world (linked to unhealthy lifestyle practices and increasing urbanization) has led to many people (even in advanced economies) resorting to plant-based diets and therapeutic options $[2,3]$. This is mainly due to the several reported benefits associated with many plants and plant-based diets as well as their perceived safety compared to synthetic supplements and drugs.

Jatropha tanjorensis (Euphorbiaceae) is another plant widely used in traditional medicine and as a vegetable in Nigeria and popularly known as "hospital too far" or Iyana-Ipaja in the Nigerian local languages. Many people in the southern part of Nigeria consume the leaves as vegetables in soups and it is also popularly used in the treatment of diabetes, malaria, and anemia $[4,5]$.

(c) The Author(s). 2021 Open Access This article is licensed under a Creative Commons Attribution 4.0 International License, which permits use, sharing, adaptation, distribution and reproduction in any medium or format, as long as you give appropriate credit to the original author(s) and the source, provide a link to the Creative Commons licence, and indicate if changes were made. The images or other third party material in this article are included in the article's Creative Commons licence, unless indicated otherwise in a credit line to the material. If material is not included in the article's Creative Commons licence and your intended use is not permitted by statutory regulation or exceeds the permitted use, you will need to obtain permission directly from the copyright holder. To view a copy of this licence, visit http://creativecommons.org/licenses/by/4.0/. 
Scientific evidences also abound attesting to the medicinal properties of this plant [6] reported its protective effect against xenobiotic-induced organ damage. The plant's potential as a treatment for cardiovascular diseases has also been reported [7], as well as its antibacterial and anti-anemic effects [5, 8].

In Africa and especially in Nigeria, many plants and plant parts are being incorporated into diets or formulated and commercialized by herbal practitioners into herbal products with several claims of their health benefits. However, there have been concerns about the potential risk of toxicity associated with the consumption of some herbal products and vegetables $[9,10]$. Some constituents of medicinal plants are associated with toxic outcomes including certain alkaloids (tropane, quinoline and isoquinoline, lupin, senecio, and pyridine-piperidine alkaloids), glycosides (cyanophoric, cardiac, steroidal, and lactone glycosides), and proteins (toxalbumines) [11]. There is, therefore, a need to ascertain the safety of these plants scientifically and not rely completely on ethnomedicinal claims of their potency and safety. In view of this, we carried out this study to determine the acute and sub-acute toxicity of Jatropha tanjorensis leaves (Fig. 1).

\section{Methods}

\section{Preparation of plant material}

Fresh leaves of Jatropha tanjorensis were collected from Nsukka in Enugu State of Nigeria and identified by a taxonomist at the Bioresource Development and Conservation Programme (BDCP), Nsukka, Enugu State, Nigeria. The leaf samples were deposited in their herbarium with voucher number InterCEDD/16045. The leaves were then air dried and pulverized, and $350 \mathrm{~g}$ of the

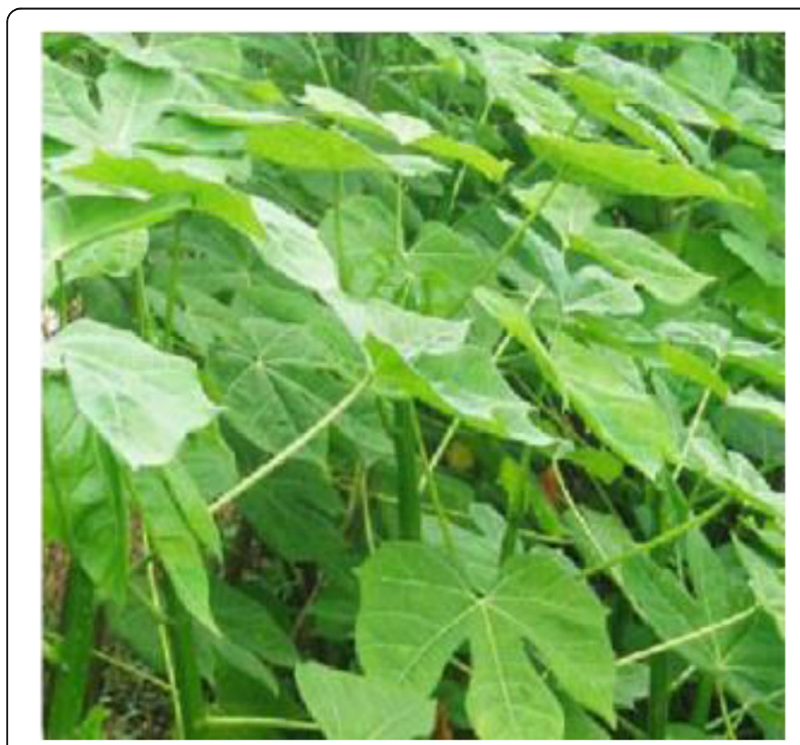

Fig. 1 Jatropha tanjorensis leaves powdered leaves was extracted by maceration in $1.4 \mathrm{~L}$ of 98\% methanol for $48 \mathrm{~h}$. This was followed by filtration, first with a mesh and then with Whatman No. 1 filter paper and the filtrate concentrated using rotary evaporator at $40{ }^{\circ} \mathrm{C}$ to obtain the crude methanol extract (JTME).

\section{Phytochemical analysis}

The methods of $[12,13]$ were adopted for the preliminary phytochemical analyses of the extract. The extract was screened for the presence of flavonoids, alkaloids, tannins, terpenoids, carbohydrates, and steroids.

\section{Experimental animals}

Eighteen male albino mice of average body weight of 25 $\mathrm{g}$ and 24 male albino rats of the Wistar strain (6-8 weeks old and 85-150 g average weight) were used respectively for the acute and sub-acute toxicity study. They were kept in clean animal cages with proper ventilation and acclimatized to laboratory environment for 7 days while being maintained on standard animal feed (Vital feeds) and water ad libitum. Animal cages were cleaned every 3 days throughout the experimental period. The animals were handled in accordance with the relevant ethical guidelines compliant with the International Standard for the use of laboratory animals.

\section{Experimental design}

For the acute toxicity study, the protocol of [14] was adopted. The mice were administered, by oral intubation, doses of 10, 100, and $1000 \mathrm{mg} / \mathrm{kg}$ b.wt of the extract in the first phase and monitored for $24 \mathrm{~h}$ for any signs of toxicity. Due to the absence of any toxic sign or mortality, the doses were increased to 1600,2900 , and $5000 \mathrm{mg} / \mathrm{kg}$ b.wt in the second phase and administered to another group.

For the sub-acute toxicity studies, the method described by the Organization for Economic Cooperation and Development (OECD) [15] was adopted. The OECD guideline for sub-acute toxicity studies requires oral administration of graduated doses of a test substance to experimental animals daily for a period of 28 days using a minimum of three test groups along with a control group. In this study, 24 rats were distributed to four groups $(\mathrm{n}=6)$ with group 1 (control group) administered $1 \mathrm{ml}$ distilled water while groups $2-4$ (test groups) were administered, by oral gavage, $100 \mathrm{mg} / \mathrm{kg}, 200 \mathrm{mg} /$ $\mathrm{kg}$, and $400 \mathrm{mg} / \mathrm{kg}$ body weight of the extract respectively for the duration of the experiment. Extract administration lasted for 28 days while the average body weight for each group was taken weekly and recorded. On the 29th day, the animals were weighed and then euthanized under mild chloroform anesthesia. Blood samples were collected from the orbital sinus into ethylene 
Table 1 Phytochemical constituent of JTME

\begin{tabular}{ll}
\hline Phytochemicals & Amount $\mathbf{( m g / g )}$ \\
\hline Tannins & $0.70 \pm 0.07$ \\
Flavonoids & $3.16 \pm 0.43$ \\
Terpenoids & $2.09 \pm 0.48$ \\
Alkaloids & $1.67 \pm 0.42$ \\
Steroids & $0.26 \pm 0.09$ \\
Carbohydrates & $1.34 \pm 0.23$ \\
\hline
\end{tabular}

diamine tetra-acetic acid (EDTA)-lined sample bottles for hematological analysis and plain sample bottles for biochemical analysis. Blood samples for the biochemical analyses was allowed to clot and centrifuged at 4000 rpm for $30 \mathrm{~min}$ to obtain the serum which was stored at $4{ }^{\circ} \mathrm{C}$ in a refrigerator until use.

Estimation of hematological and biochemical parameters Hematological parameters (RBC, PCV, Hb, PLT, and WBC) were estimated using the methods described by $[16,17]$. Biochemical parameters were determined using commercially available kits. Total bilirubin concentration was determined by colorimetric method described by [18]. Alanine aminotransferase (ALT) and aspartate aminotransferase (AST) activities were assayed following the protocol of [19]. Alkaline phosphatase (ALP) activity was assayed by the method of [20]. Lipid peroxidation was determined by the method described by [21]. Total protein in whole blood was determined according to the method of [22]. Serum urea and creatinine concentrations were determined using the method of [23].

\section{Histopathological examination}

Tissue samples from the liver and kidneys were also collected after dissecting the rats, fixed in $10 \%$ phosphatebuffered formalin, and prepared for histopathological examination. Hematoxylin- and eosin-stained tissues on different slides were examined using a compound light microscope with $\times 4, \times 10$, and $\times 40$ objective lenses. The photomicrographs were taken using Motic $\bigodot 9$ 9megapixel microscope camera at magnifications $\times 100$ and $\times 400$.

\section{Statistical analysis}

Statistical analysis of obtained data was carried out using the Statistical Product and Service Solution (SPSS, version 21.0). All data were expressed as mean \pm standard deviation (SD) and statistical different between means were determined by one-way analysis of variance (ANOVA).

\section{Results}

The phytochemical analysis of the methanol extract of Jatropha tanjorensis leaves revealed the presence of flavonoids, alkaloids tannins, steroids, and terpenoids (Table 1) while the total phenolic content of the extract is $129.8 \pm 10.2 \mathrm{mg}$ GAE.

\section{Effect of JTME on weight gain of experimental animals}

The result presented in Fig. 2 below shows that the extract caused a dose-dependent reduction in percentage weight gain in the JTME groups when compared to the control group.

\section{Effect of JTME on hematological parameters of experimental animals}

The result presented in Table 2 shows that administration of JTME for 28 days caused a significant $(\mathrm{p}<0.05)$ increase in $\mathrm{PCV}, \mathrm{RBC}$, and $\mathrm{Hb}$ concentration in groups 3 and 4 given $200 \mathrm{mg} / \mathrm{kg}$ and $400 \mathrm{mg} / \mathrm{kg}$ respectively in comparison to the control group. Also, there were no significant changes in WBC and PLT levels in the experimental rats except for group $4(400 \mathrm{mg} / \mathrm{kg})$ which had significantly $(\mathrm{p}<0.05)$ reduced WBC and a significant $(\mathrm{p}<0.05)$ increase in PLT levels when compared to control.

\section{Effect of JTME on some biochemical parameters of experimental rats}

The result presented in Table 3 shows that there was no significant change in serum levels of creatinine, blood urea nitrogen (BUN), total protein, and total bilirubin of the JTME groups when compared to control. On the other hand, in comparison with the control group, all the doses significantly reduced AST activity in the JTME groups while ALP activity was significantly reduced in

Table 2 Hematological parameters of rats administered with JTME for 28 days

\begin{tabular}{lllll}
\hline Hematological parameters & $\begin{array}{l}\text { Grp 1 } \\
\text { (control) }\end{array}$ & $\begin{array}{l}\text { Grp 2 } \\
(\mathbf{1 0 0} \mathbf{~ m} / \mathbf{k g})\end{array}$ & $\begin{array}{l}\text { Grp 3 } \\
\mathbf{( 2 0 0} \mathbf{~ m g / k g})\end{array}$ & $\begin{array}{l}\text { Grp 4 } \\
\mathbf{( 4 0 0} \mathbf{~ m g / k g})\end{array}$ \\
\hline PCV (\%) & $39.33 \pm 1.37^{\mathrm{a}}$ & $41.33 \pm 1.11^{\mathrm{a}}$ & $46.33 \pm 2.05^{\mathrm{b}}$ & $45.17 \pm 2.62^{\mathrm{b}}$ \\
RBC $\left(10^{6} / \mathrm{L}\right)$ & $286.67 \pm 17.95^{\mathrm{a}}$ & $301.67 \pm 9.43^{\mathrm{a}}$ & $340 \pm 20^{\mathrm{b}}$ & $330 \pm 15.55^{\mathrm{b}}$ \\
Hb (g/dl) & $8.23 \pm 0.69^{\mathrm{a}}$ & $8.95 \pm 0.88^{\mathrm{a}}$ & $10.23 \pm 0.46^{\mathrm{b}}$ & $9.92 \pm 0.69^{\mathrm{b}}$ \\
WBC $\left(10^{3} / \mathrm{L}\right)$ & $5000 \pm 275.41^{\mathrm{a}}$ & $4966.7 \pm 314.47^{\mathrm{a}}$ & $4933.3 \pm 306.32^{\mathrm{a}}$ & $4866.7 \pm 392.44^{\mathrm{b}}$ \\
PLT $\left(10^{3} / \mathrm{L}\right)$ & $136.50 \pm 24.67^{\mathrm{a}}$ & $143.5 \pm 25.81^{\mathrm{a}}$ & $143.83 \pm 16.00^{\mathrm{a}}$ & $148.5 \pm 25.50^{\mathrm{b}}$ \\
\hline
\end{tabular}

Data represent mean \pm SD $(n=6)$; values with dissimilar alphabets as superscripts are significant at $p<0.05$ 


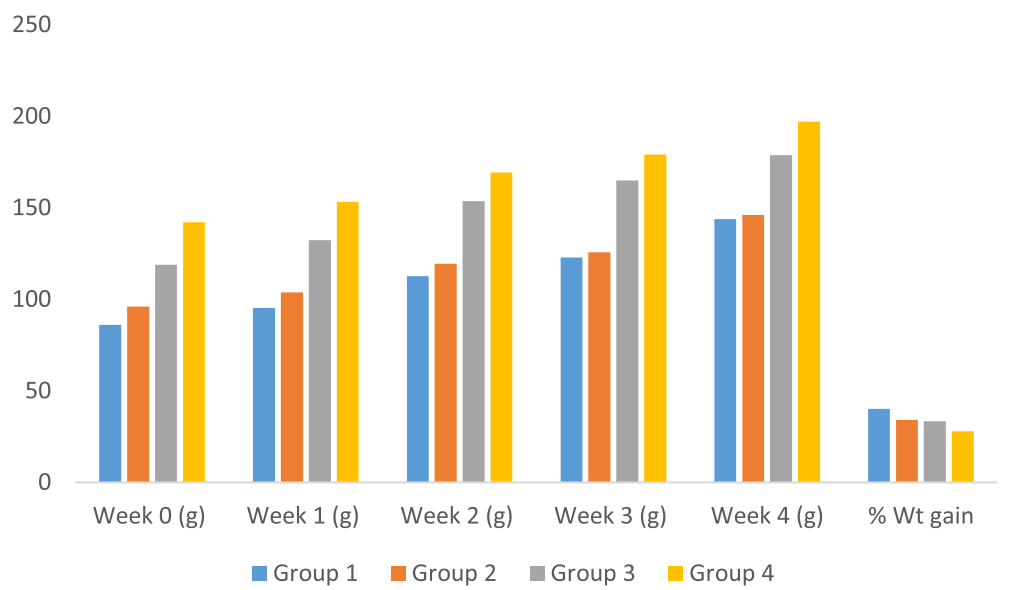

Fig. 2 Body weight of rats administered with JTME for 28 days

groups 3 and 4 which received $200 \mathrm{mg} / \mathrm{kg}$ and $400 \mathrm{mg} /$ $\mathrm{kg}$ doses of JTME respectively.

\section{Histopathological assessment of liver and kidney tissues of experimental rats (Plates 1, 2, 3, 4, 5, 6, 7, and 8)}

\section{Discussion}

In many nations of the world, many green leafy plants are regularly consumed either as vegetables or as medicinal herbs without consideration to the potential toxicity of these plants. This study evaluated the toxicity of the methanol extract of Jatropha tanjorensis leaves (JTME) employing a 24-h acute toxicity and 28 days repeated dosing regimen. The acute toxicity result showed that a dose of $5000 \mathrm{mg} / \mathrm{kg}$ body weight of JTME orally administered to mice did not cause any signs of toxicity or mortality in the mice. If we consider the reports of [24] that substances with $\mathrm{LD}_{50}$ higher than $5000 \mathrm{mg} / \mathrm{kg}$ when orally administered may be deemed non-toxic, we could presume that the plant is safe for oral consumption. This observation compliments earlier studies by
$[25,26]$ who also reported $\mathrm{LD}_{50}$ greater than $5000 \mathrm{mg} /$ $\mathrm{kg}$ for this plant. This result is, however, contrary to what was reported by [27] where the $\mathrm{LD}_{50}$ of the aqueous extract of Jatropha tanjorensis leaves was found to be $1161.89 \mathrm{mg} / \mathrm{kg}$. This disparity could be a result of the difference in extraction solvent, that is, they extracted with distilled water as opposed to methanol used for this study. Environmental conditions may have also played a role because the plants were obtained from different locations which could have affected the constituents of the plant material.

Toxicological assessment following 28-day repeated dosing usually provides proof of possible health risks associated with the test substance. Thus, in the present study, three different doses of JTME (100, 200, and 400 $\mathrm{mg} / \mathrm{kg}$ ) were administered to rats. In this study, we observed a reduction in weight gain as the dose of extract increased. The reduction could be a result of decreased water and food intake by the rats [28] or probably a proof of the anti-obesity capabilities of the plant [26]. reported the hypolipidemic effect of this plant attributing

Table 3 Biochemical parameters of rats administered with JTME for 28 days

\begin{tabular}{lllll}
\hline Parameters & $\begin{array}{l}\text { Grp 1 } \\
\text { (control) }\end{array}$ & $\begin{array}{l}\text { Grp 2 } \\
(\mathbf{1 0 0} \mathbf{~ m g / k g})\end{array}$ & $\begin{array}{l}\text { Grp 3 } \\
\mathbf{( 2 0 0} \mathbf{~ m g / k g})\end{array}$ & $\begin{array}{l}\text { Grp 4 } \\
\mathbf{( 4 0 0} \mathbf{~ m g / k g})\end{array}$ \\
\hline Total protein $(\mathrm{mg} / \mathrm{dl})$ & $6.95 \pm 1.38^{\mathrm{a}}$ & $6.05 \pm 0.50^{\mathrm{a}}$ & $6.08 \pm 0.67^{\mathrm{a}}$ & $6.17 \pm 0.63^{\mathrm{a}}$ \\
Total bilirubin $(\mu \mathrm{mol} / \mathrm{L})$ & $1.57 \pm 0.28^{\mathrm{a}}$ & $1.58 \pm 0.31^{\mathrm{a}}$ & $1.32 \pm 0.17^{\mathrm{a}}$ & $1.28 \pm 0.23^{\mathrm{a}}$ \\
AST (IU/L) & $94.00 \pm 6.45^{\mathrm{b}}$ & $76.83 \pm 17.77^{\mathrm{a}}$ & $74.00 \pm 16.32^{\mathrm{a}}$ & $77.67 \pm 10.82^{\mathrm{a}}$ \\
ALT (IU/L) & $22.17 \pm 7.14^{\mathrm{a}}$ & $24.33 \pm 6.86^{\mathrm{a}}$ & $17.17 \pm 2.48^{\mathrm{a}}$ & $18.83 \pm 6.59^{\mathrm{a}}$ \\
ALP (IU/L) & $72.67 \pm 4.97 \mathrm{~b}^{\mathrm{c}}$ & $74.33 \pm 4.23^{\mathrm{c}}$ & $63.83 \pm 3.76^{\mathrm{a}}$ & $68.00 \pm 4.38^{\mathrm{ab}}$ \\
BUN (mmol/L) & $26.50 \pm 7.06^{\mathrm{a}}$ & $24.50 \pm 5.96^{\mathrm{a}}$ & $23.17 \pm 6.55^{\mathrm{a}}$ & $24.67 \pm 7.74^{\mathrm{a}}$ \\
Creatinine (mg/dl) & $0.85 \pm 0.10^{\mathrm{a}}$ & $0.82 \pm 0.10^{\mathrm{a}}$ & $0.75 \pm 0.03^{\mathrm{a}}$ & $0.83 \pm 0.12^{\mathrm{a}}$ \\
MDA (mg/ml) & $1.61 \pm 0.34^{\mathrm{a}}$ & $1.14 \pm 0.31^{\mathrm{b}}$ & $0.82 \pm 0.34^{\mathrm{b}}$ & $0.96 \pm 0.29^{\mathrm{b}}$ \\
\hline
\end{tabular}

Data represent mean $\pm S D(n=6)$; values with dissimilar alphabets as superscripts are significant at $p<0.05$ 


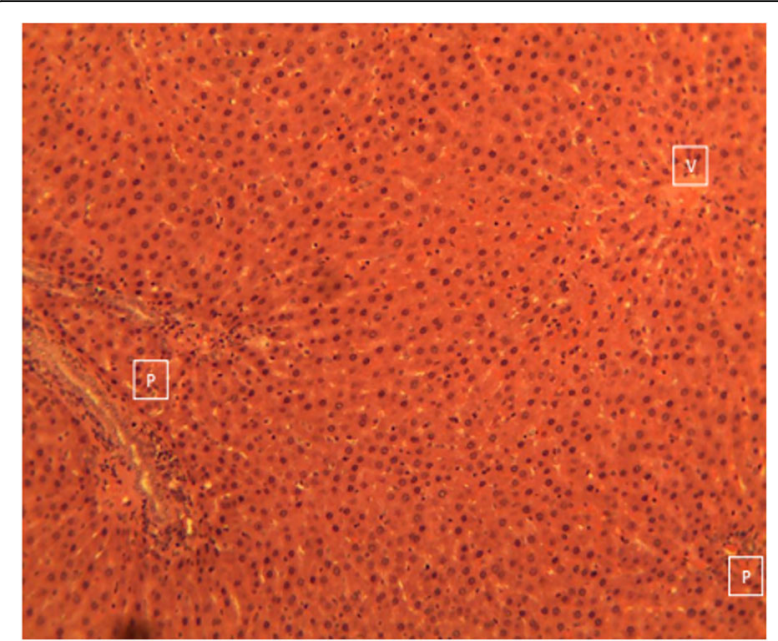

Plate 1 Photomicrograph of a section of the liver from group 1 showing the normal histo-architecture of the mammalian liver.

it to the rich polyphenolic content which has been shown to inhibit adipocyte growth and excessive storage of lipids [29].

Due to its role in the transport of nutrients and other materials in the body, blood components are usually at the frontline during exposure to xenobiotic substances, some of which may be toxic. Thus, analysis of the different hematological parameters gives an idea of the physiological and pathological status of the body. The hematological analysis gave a mixed result as the higher doses of $200 \mathrm{mg} / \mathrm{kg}$ and $400 \mathrm{mg} / \mathrm{kg}$ induced significant increases in $\mathrm{RBC}, \mathrm{PCV}$, and $\mathrm{Hb}$ levels of experimental rats in comparison to control, while a significant increase in PLT levels was only observed in the rats administered $400 \mathrm{mg} / \mathrm{kg}$ dose of the extract. This result further supports the claims of the anti-anemic effect of

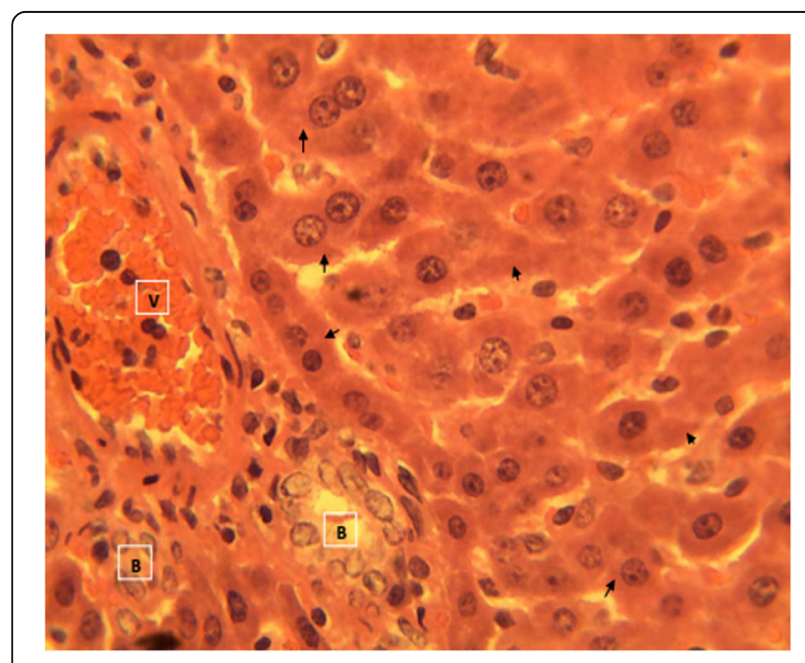

Plate 2 Photomicrograph of the liver from the experimental animals in group 2 showing the normal hepatic histo-architecture

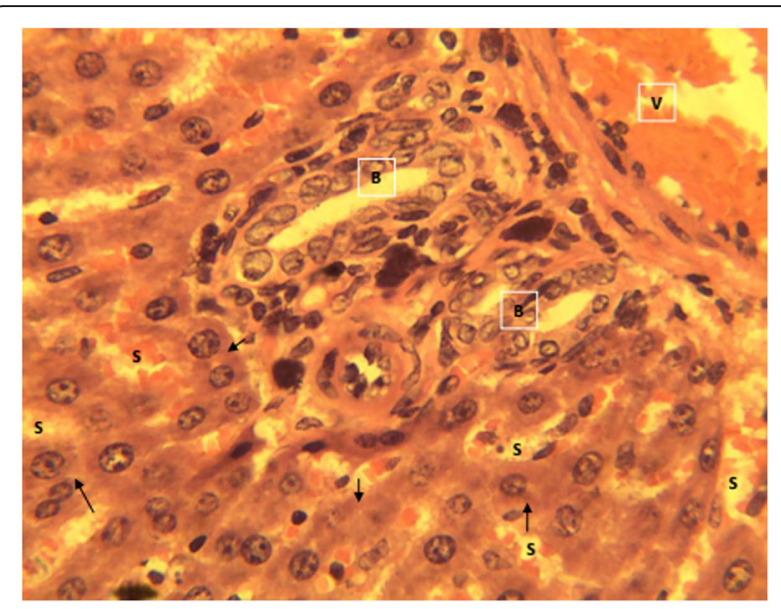

Plate 3 A photomicrograph of the liver from the animals in group 3 showing the normal hepatic histo-architecture

this plant [27]. reported the hematopoietic effect of this plant when administered to Plasmodium berghi-berghiinfected mice. The improvement of red cell indices of experimental animals suggests safety of the extract to blood components. On the other hand, there was an observed reduction in WBC (though non-significantly) with increasing doses of the extract which may be an indication of slight suppression of immune function by the extract [30].

Vital organs such as the liver and kidneys are susceptible to toxicity by herbal products due to their involvement in metabolism and excretion of xenobiotic substances. Assay of liver enzymes are used in the differential diagnosis of liver diseases or injury and excessive increase in the activities of these enzymes is indicative of liver damage. All the doses of the extract significantly decreased AST activity in the JTME groups compared to

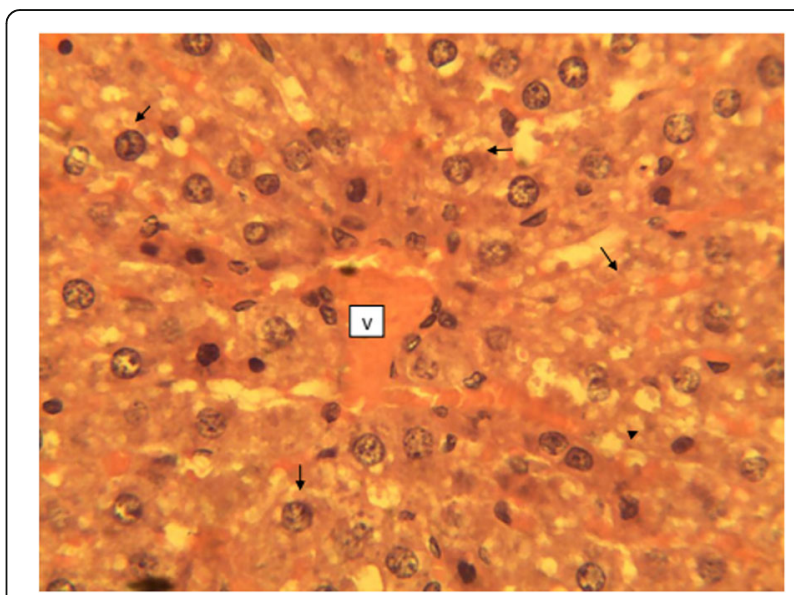

Plate 4 A photomicrograph of the liver collected from the animals in 4 showing mild to moderate vacuolar degeneration of the centrilobular to mid-zonal hepatocytes 


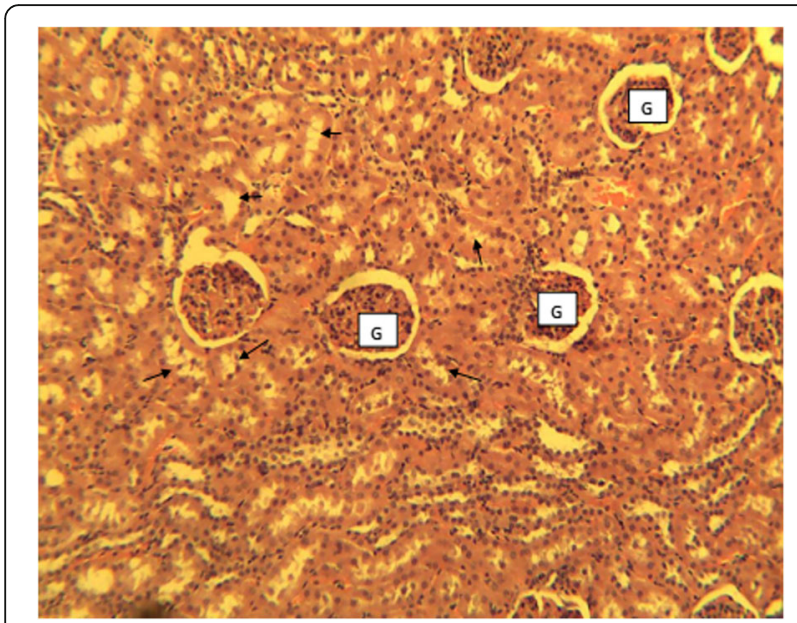

Plate 5 A photomicrograph of the kidney collected from the experimental animals in group 1 showing no change from the normal mammalian renal histo-architecture

control whereas, no significant change in ALT activity was observed between the control and test groups. On the other hand, only $200 \mathrm{mg} / \mathrm{kg}$ dose of the extract caused a significant reduction in ALP activity when compared to control. Overall, the extract did not increase the activities of the hepatic enzymes assayed and could be considered safe for consumption. Although may be considered non-significant, we observed that a dose of $400 \mathrm{mg} / \mathrm{kg}$ increased serum activities of these enzymes in comparison to the lower doses. This, coupled with the slight reduction in total protein (TP) of experimental rats compared to control (suggestive of reduced protein synthesis), may indicate a slight regression in hepatic function of the JTME groups [30].

Changes in urea nitrogen and creatinine are commonly used for assessment of renal function, and renal

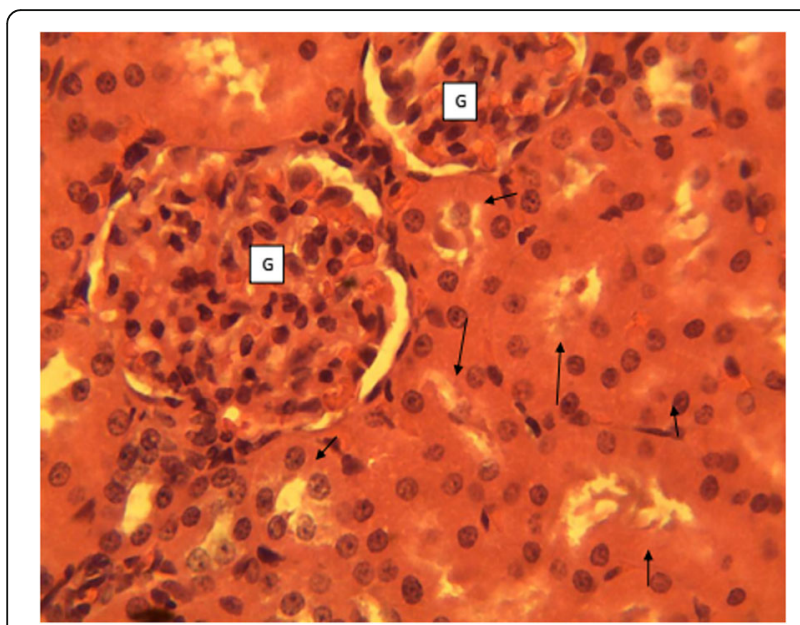

Plate 6 A photomicrograph of the kidney collected from the experimental animals in group 2 showing no change from the normal mammalian renal histo-architecture

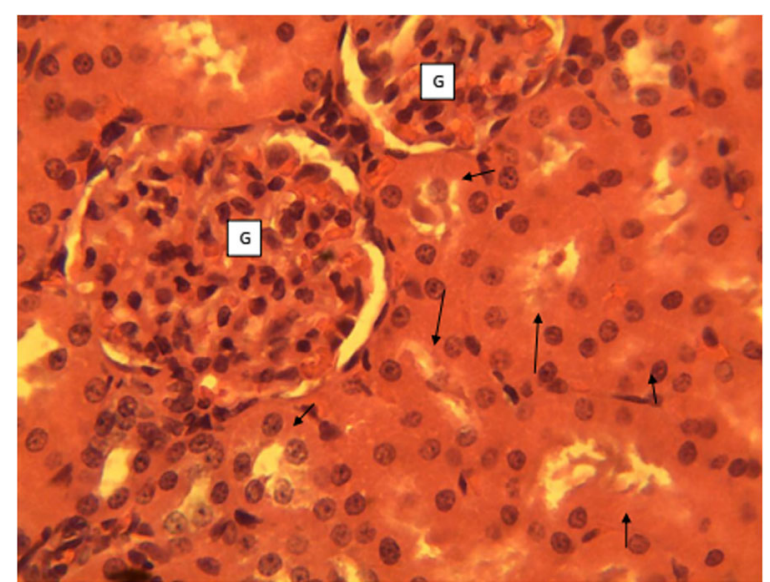

Plate 7 A photomicrograph of the kidney from the experimental animals in group 3 showing no change from the normal mammalian renal histo-architecture

injury is usually suspected when serum levels of these parameters increase [31]. In this study, the extract caused no significant change in serum creatinine and urea levels of the JTME groups in comparison with control indicating no harm to the kidneys. The result also showed that all the doses of the extract induced a significant reduction in MDA levels in the JTME groups when compared to control suggesting the potentials of the extract in protecting cells from the damaging effects of toxic reactive species. This is supported by the reports of $[6,32]$ who reported the ameliorative effect of the plant on calcium chloride- and sodium benzoate-mediated organ damage respectively.

The histopathological examination of the liver and kidney sections of experimental animals revealed that JTME caused no significant histological changes to the kidneys

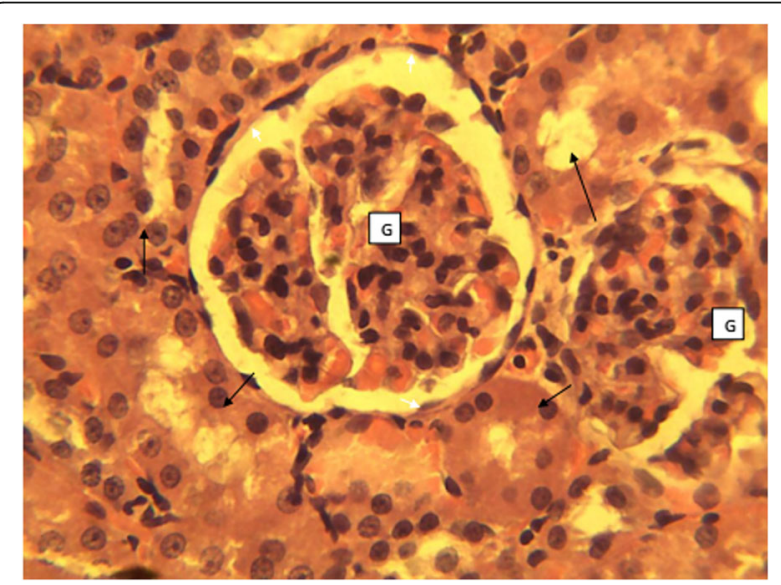

Plate $8 \mathrm{~A}$ photomicrograph of the kidney collected from the experimental animals in group 4 showing no change from the normal mammalian renal histo-architecture 
of the experimental animals. However, the highest dose of $400 \mathrm{mg} / \mathrm{kg}$ b.wt of extract caused histopathological lesions in the liver of rats. The sections showed a mild to moderate vacuolar degeneration and necrosis of the centrilobular hepatocytes of the hepatic lobules which is indicative of toxicity. Some of the factors that induce hepatic cell necrosis include anoxia, or exposure to tannic acid, chloroform, or other hepatotoxic agents [33]. From the phytochemical analysis of the extract, tannins were seen to be highly concentrated and might account for the histological change observed in this group. A similar occurrence was reported by [34] where ground Jatropha tanjorensis leaves mixed with feed of experimental rabbits caused mild necrosis of the heart, liver, and kidney of the animals.

\section{Conclusion}

The result of this study revealed that the leaf extract of Jatropha tanjorensis has a relatively positive effect on red cell indices as well as the liver and the kidney of experimental rats. However, there are slight concerns with the plant displaying hepatotoxic potentials when high doses are administered over a prolonged time. Also, the effect of the plant on WBC and other white blood cell components still needs to be determined as our results indicate possibility of immunosuppression on prolonged use.

\section{Abbreviations \\ JTME: Methanol extract of Jatropha tanjorensis leaves; WHO: World Health Organization; EDTA: Ethylene diamine tetra-acetic acid; WBC: White blood cells; RBC: Red blood cells; PLT: Platelets; PCV: Packed cell volume; Hb: Hemoglobin; AST: Aspartate aminotransferase; ALT: Alanine aminotransferase; ALP: Alkaline phosphatase; BUN: Blood urea nitrogen; MDA: Malondialdehyde}

\section{Acknowledgements \\ The authors acknowledge the contributions of Mr. Alfred Ozioko who authenticated the plant material.}

\section{Plant authentication}

The plant leaves were identified by Mr. Alfred Ozioko, a taxonomist at the Bioresource Development and Conservation Programme (BDCP), Nsukka, Enugu state, Nigeria. The leaf samples were deposited in their herbarium with voucher number InterCEDD/16045.

\section{Authors' contributions}

NOU and NOFC designed the study. CCC and NNV carried out the experimental protocol including phytochemistry and animal handling. OVEO carried out the statistical analysis of data while NOU interpreted the data. All author contributed in the manuscript preparation. All the authors have read and approved the final manuscript for publication.

\section{Funding}

No funding was received by the authors.

\section{Availability of data and materials}

All data and materials are available on request.

\section{Declarations}

\section{Ethics approval and consent to participate}

This research was approved by the Faculty of Biological Sciences' Ethics and Biosafety Committee, University of Nigeria, Nsukka, with reference UNN/FBS/
$\mathrm{EC} / 1055$, and the animals were handled in compliance with the International Standard for the use of laboratory animals.

\section{Consent for publication}

Not applicable

Competing interests

The authors declare that they have no competing interests.

Received: 6 April 2021 Accepted: 28 June 2021

Published online: 19 July 2021

References

1. van Andel T, Carvalheiro LG (2013) Why urban citizens in developing countries use traditional medicines: the case of suriname, vol 687197. Hindawi Publishing Corporation, Evidence-based Comp and Alt Med, p 13

2. Stephenson K, Kennedy L, Hargrove L, Demieville J, Thomson J, Alpini G, Francis $H$ (2018) Updates on dietary models of non-alcoholic fatty liver disease: current studies and insights. Gene Expr 18(1):5-17. https://doi.org/1 0.3727/105221617X15093707969658

3. Chan-Sik K, Sok P, Junghyun K (2017) The role of glycation in the pathogenesis of aging and its prevention through herbal products and physical exercise. J Exerc Nutr Biochem 21(3):55-61

4. Olayiwola G, Iwalewa EO, Omobuwajo OR, Adebajo AC, Adeniyi AA, Verspohl EJ (2004) The antidiabetic potential of Jatropha tanjorensis leaves. Nig J Nat Prod Med 8:55-58

5. Ansari RA, Rabiu KM, Ayuba V, Omolabake OO (2020) Review on Jatropha tanjorensis (Hospital too far); significance as an anti-anaemia plant. Int Blood Res Rev 11(4):1-7

6. Oladele JO, Oladele OT, Ademiluyi AO, Oyeleke OM, Awosanya OO, Oyewole OI (2020) Chaya (Jatropha tanjorensis) leafs protect against sodium benzoate mediated renal dysfunction and hepatic damage in rats. Clin Phytosci 6(1):13. https://doi.org/10.1186/s40816-020-00160-5

7. Oyewole OI, Akingbala PF (2011) Phytochemical analysis and hypolipidemic properties of Jatropha tanjorensis leaf extract. Eur J Med Plants 1(4):180-185. https://doi.org/10.9734/EJMP/2011/497

8. Iwalewa EO, Adewunmi CO, Omisore NO, Adebanji OA, Azike CK (2005) Prooxidant effects and cytoprotective potentials of nine edible vegetables in Southwest Nigeria. J Med Food 8(4):539-544. https://doi.org/10.1089/jmf.2 005.8.539

9. Agbaire PO, Emudainohwo JOT, Peretiemo-Clarke BO (2013) Phytochemical screening and toxicity studies on the leaves of Manniophyton fulvum. Int J Plant and Envir Sci 3(1):1-6

10. Ugwah-Oguejiofor CJ, Okoli CO, Oguejiofor-Ugwah M, Umaru ML, Ogbulie CS, Mshelia HE, Umar M, Njan AA (2019) Acute and sub-acute toxicity of aqueous extract of aerial parts of Caralluma dalzielii (N. E. Brown) in mice and rats. Hel 5:e01179

11. Ogori AF (2019) Plant toxins. Ame J Biomed Sci Res 4(3):173-175

12. Harborne JB (1973) Phytochemical Methods. Chapman and Hall Limited, London, pp 49-88

13. Trease GE, Evans WC (1989) Pharmacognosy, 11th edn. Saunders Publishers, London, pp 42-44 221-229, 246-249, 404-306, 331-332, 391-393

14. Lorke D (1983) A new approach to practical acute toxicity testing. Arch Toxicol 53:275-289

15. OECD (1995) OECD guideline for testing of chemicals: repeated dose 28 day oral toxicity study in rodents (No. 407), Section 4. OECD Publishing, pp 1-8

16. Miale JB (1972). Laboratory Medicine: Heamatology. CV Mosby Co., St. Louis, p. 494.

17. Ochei J, Kolhatkar A (2008) Medical Laboratory Sciences: Theory and Practice. Tata McGraw Hill, New York, pp 663-665

18. Jendrassik J, Grof P (1938) In vitro determination of total and direct bilirubin in serum or plasma. Biochem. 6:269-275

19. Reitman S, Frankel SA (1957) Colorimetric method for the determination of serum glutamic oxaloacetic and glutamic pyruvic transaminases. Am J Clin Pathol 28:56-63

20. Englehardt A (1970) Measurement of alkaline phosphatase. Aerzt Laboratory 16:42-43

21. Wallin B, Rosengren B, Shertzer HG, Camejo G (1993) Lipoprotein oxidation and measurement of TBARS formation in a single microliter plate: Its use for evaluation of antioxidants. Anal Biochem 208(1):10-15. https://doi.org/10.1 006/abio.1993.1002 
22. Tietz NW (1995) Clinical Guide to Laboratory Test, 3rd edn. W.B. Saunders Company, Philadelphia, pp 518-519

23. Cheesbrough M (2005) Measurement of serum or plasma creatinine and urea. In: District Laboratory Practice in Tropical Countries, 2nd edn. Cambridge University Press, Cambridge, pp 333-340. https://doi.org/10.101 7/CBO9780511581304

24. Kennedy GL, Ferenz RL, Burgess BA (1986) Estimation of acute oral toxicity in rats by determination of the approximate lethal dose rather than the LD ${ }_{50}$. J Appl Toxicol 6(3):145-148. https://doi.org/10.1002/jat.2550060302

25. Idu M, Igbafe G, Erhabor J (2014) Anti-anaemic activity of Jatropha tanjorensis in rabbits. J Med Plants Stud 2(1):64-72

26. Ijioma SN, Okafor Al, Ndukuba Pl, Akomas SC (2014) Hypoglycemic, haematologic and hypolipidemic activity of Jatropha tanjorensis ethanol leaf extract in alloxan-induced diabetic rats. Ann Biol Res 5(10):1-6

27. Ndem Jl, Bassey El, Effiong BO, Bassey UE, Ini SD (2019) Haematopoietic potential of Jatropha tanjorensis leaf extract in Plasmodium berghi-berghi infected mice treated with Hippocratea africana root bark extract. J Dis Med Plants 5(4):69-73

28. Rivas CA, Berenguer A, Castillo A, Martínez HS, Zapata EP, Hernández JB, Tassé YM (2013) Acute oral toxicity of Azadirachta indica (Neem tree). Rev Cubana Plantas Med 18(3):502-507

29. Badimon L, Vilahur G, Padro T (2010) Nutraceuticals and atherosclerosis: Human trials. Cardiovas Ther 28(4):202-215. https://doi.org/10.1111/j.17555922.2010.00189.x

30. Yang M, Wu Z, Wang Y, Kai G, Njateng GSS, Cai S, Cao J, Cheng G (2019) Acute and subacute toxicity evaluation of ethanol extract from aerial parts of Epigynum auritum in mice. Food Chem Toxicol 131:110534. https://doi. org/10.1016/j.fct.2019.05.042

31. Ezeja MI, Anaga AO, Asuzu IU (2014) Acute and sub-chronic toxicity profile of methanol leaf extract of Gouania longipetala in rats. J Ethnopharmacol 151(3):1155-1164. https://doi.org/10.1016/j.jep.2013.12.034

32. Ochulor OC, Njoku OU, Uroko RI, Egba SI (2018) Nutritional composition of Jatropha tanjorensis leaves and effects of its aqueous extract on carbon tetrachloride induced oxidative stress in male Wistar albino rats. Biomed Res 29(19):3569-3576

33. Gopinath C, Prentice DE Lewis DJ (1987) The liver. In Atlas of Experimental Toxicological Pathology (Grasham G.A Ed.), vol 13. MTP Press limited, Lancaster, pp 43-60

34. Orhue ES, Idu M, Ataman JE, Ebite LE (2008) Haematological and histopathological studies of Jatropha tanjorensis leaves in rabbits. Asian $J$ Biol Sci 1(2):84-89. https://doi.org/10.3923/ajbs.2008.84.89

\section{Publisher's Note}

Springer Nature remains neutral with regard to jurisdictional claims in published maps and institutional affiliations.

\section{Submit your manuscript to a SpringerOpen ${ }^{\circ}$ journal and benefit from:}

- Convenient online submission

- Rigorous peer review

- Open access: articles freely available online

- High visibility within the field

- Retaining the copyright to your article

Submit your next manuscript at $\boldsymbol{\nabla}$ springeropen.com 